\title{
Associations between fish assemblage and riparian vegetation in the Corumbataí River Basin (SP)
}

\author{
Cetra, M. ${ }^{\mathrm{a}^{*}}$ and Petrere JR., M. ${ }^{\mathrm{b}}$ \\ aDepartamento de Ciências Exatas e Tecnológicas - DCET, Universidade Estadual de Santa Cruz - UESC, \\ Rodovia Ilhéus, Itabuna, Km 16, Salobrinho, CEP 45650-000, Ilhéus, BA, Brazil \\ ${ }^{b}$ Departamento de Ecologia, Instituto de Biociências, Universidade Estadual Paulista - UNESP, \\ CEP 13506-900 Rio Claro, SP, Brazil \\ *e-mail: mcetra@uesc.br
}

Received January 17, 2005 - Accepted August 26, 2005 - Distributed May 31, 2007

(With 2 figures)

\begin{abstract}
This work intends to examine if there are associations between fish species and the state of conservation of the riparian forest in the Corumbataí River Basin. Four main rivers were chosen for this study with three sites on each. Collections were carried out from March to June and from September to December 2001. Multivariate techniques were applied to determine the correlation between species richness and the order of the rivers, preservation level of the riparian forest, shade level, presence or absence of Eucalyptus, sugar cane and pastures, and surrounding declivity stability of the sites. Species richness was highest at locations with greater vegetation cover and preserved riparian forest.
\end{abstract}

Keywords: Paraná River Basin, Corumbataí river, fish assemblage, riparian vegetation.

\section{Associações entre assembléia de peixes e a mata ciliar na bacia do rio Corumbataí (SP)}

\begin{abstract}
Resumo
Este trabalho teve o objetivo de examinar se existem associações entre as espécies de peixes e o estado de conservação das matas ciliares na bacia do rio Corumbataí. Foram escolhidos 4 rios principais com 3 pontos de coleta em cada um. Foram realizadas coletas nos períodos de março a junho e de setembro a dezembro de 2001. Técnicas multivariadas foram aplicadas para determinar a correlação entre a riqueza de espécies e a ordem dos rios, estado de preservação da mata ciliar, sombreamento, presença ou ausência de Eucalyptus, cana-de-açúcar e pastagens, e nível de estabilidade do barranco ao redor dos pontos de coleta. A riqueza de espécies foi maior em locais com maior cobertura vegetal e mata ciliar preservada.
\end{abstract}

Palavras-chave: bacia do Rio Paraná, Rio Corumbataí, assembléia de peixes, mata ciliar.

\section{Introduction}

Riparian forest zones exhibit hydrological, ecological and limnological functions important to the biotic and abiotic integrity of river systems (Zalewski et al., 2001, Barrella et al., 2000). According to these authors, in the stretches where the water volume is relatively small, the influence of vegetation is large. This is because vegetation regulates the water flow, provides shelter and organic matter and substrate for algae and periphyton attachment.

The removal of bank vegetation causes many changes in lotic systems, including increased water temperature, substitution of a heterotrophic for an autotrophic system and the loss of sediment and nutrient retention capacity (Angermeier and Karr, 1983; Allan, 1995).

Environmental analyses based on fish assemblage have numerous advantages due to the information available about the life cycles of a large number of species and to the inclusion of several feeding habits (omnivores, herbivores, insectivores, planktovores, carnivores), allowing the understanding of both the aquatic and terrestrial resources. Another advantage is the possibility of encountering this group at the top of the food chain, which provides an integrated vision of the aquatic environment (Harris, 1995).

This study examines if there are associations between fish species and the state of conservation of the riparian forest in the Corumbataí River Basin, in the state of São Paulo, Brazil.

\section{Materials and Methods}

\subsection{Description of the study area}

The Corumbataí River Basin includes an area of approximately $1690 \mathrm{~km}^{2}$ that contains around 13\% 
of the hydrographical basin of the Piracicaba, Jundiaí and Capivari rivers, which is a São Paulo State Water Resource Management unit. The study area is located between the meridians of $47^{\circ} 30^{\prime}$ ' and $47^{\circ} 50^{\prime}$ 'West and the latitudes of $22^{\circ} 05^{\prime}$ and $22^{\circ} 30^{\prime}$ South (ATLAS..., 2002).

The climate is of the Cwa type in the Köppen classification, which is subtropical, dry in the winter and rainy in the summer, with annual mean temperatures varying between 20 and $23.7^{\circ} \mathrm{C}$ in January and between 14.9 and $17.1^{\circ} \mathrm{C}$ in July (ATLAS..., 2002).

There is currently only $9 \%$ of the original vegetation cover, $6 \%$ of which corresponds to riparian forest fragments in the Corumbataí River Basin and these fragments assume the key role as "biodiversity islands" (Viana \& Mendes, 1997).

The waters of the Piracicaba River Basin are in a critical state, while those of the Corumbataí River Basin are of high quality. Despite its being located on the bank of the voluminous Piracicaba River, the high quantity of chemical residues requires that the city of Piracicaba use $100 \%$ of the water of the Corumbataí system to supply its population (ATLAS..., 2002).

Rio Claro is the most important city of the Corumbataí Basin with a population of 163,000 , which represents $79.5 \%$ of the total population in this basin. Of the total pollution generated in the Corumbataí Basin, around $30 \%$ is of industrial origin, while $70 \%$ comes from the sewage systems. Of all of the generated domestic sewage $98 \%$ is collected, however, only $5 \%$ of that is effectively treated. It is estimated that in Rio Claro, 97\% of the pollution comes from sewage and the other $3 \%$ is of industrial origin (ATLAS..., 2002). Therefore sewage is the main pollutant in the Corumbataí system.

The Ribeirão Claro River shows large anthropic alterations, including two dams. The one in the middle stretch is used to supply water to the city of Rio Claro. Below this dam, untreated sewage is drained into the river along a stretch of about $3 \mathrm{~km}$. The other dam is in the low stretch, and was previously used for the generation of energy.

\subsection{Fish sampling}

During 2001, 2 collections were performed at 12 sites: one from March to June and the other between September and December. The collections were performed in four of the main rivers of the basin: the Passa Cinco, the Cabeça, the Corumbataí and the Ribeirão Claro. In each river, three stretches of around $150 \mathrm{~m}$ were sampled in the downstream direction.

Fishes were sampled with a series of gillnets (3 to $9 \mathrm{~cm}$ mesh, opposite knots) and with 3 pairs of sieves. The nets and sieves were placed in the afternoon (between 15 and 18 hours) and left until the following morning (between 7 and 9 hours). Nets were placed and distributed along the margins in each point in a random way. Pairs of traps were placed in suitable places along the channel.

\subsection{Habitat elements}

The following habitat elements were recorded: the order of the rivers $(4,5$ and 6$)$; the preservation level of the riparian forest: preserved, partially deforested and totally deforested; the shade level: 0-25, 26-50, 51-75 and above $76 \%$; Eucalyptus sp.: presence or absence; sugar cane: presence or absence; pastures: presence or absence; sewage drainage: presence or absence; the surrounding declivity stability: low or high.

\subsection{Data analysis}

To analyze the structure of the fish assemblages a detrended correspondence analysis (DCA) was applied (Gauch, 1982). The first two axes of the DCA, and the scores of the 35 collected species, were used to visualize the data in two dimensions. The weight of the rare species was reduced.

A principal component analysis (PCA) was applied to reduce the dimensionality of the data of the habitat elements. The number of principal components was determined by the Kaiser-Guttman criterion (components with eigenvalue less than one were removed) (McGarigal et al., 2000).

A nonparametric analysis of variance was applied (Kruskal-Wallis test) for the axes 1 and 2 of the DCA. The different rivers were considered as independent groups.

Multiple regression analyses were applied to quantify the relationship between species richness, different axes of the PCA and species abundance (number of individuals) (Marsh-Matthews \& Matthews, 2000).

\section{Results}

The detrended correspondence analysis (DCA) indicated that Astyanax fasciatus (Afas), Pimelodella gracilis (Pgra) and Hypostomus regani (Hreg) are associated with point 2 of the Corumbataí, just as Triportheus angulatus (Tang), Parodon tortuosus (Ptor) and Hyphessobrycon eques (Hequ) are associated with site 3 (Figure 1). Hoplosternum littorale (Hlit) is associated with point 3 of the Ribeirão Claro river. Maximum abundance of Salminus hilarii (Shil), Prochilodus lineatus (Plin) and Leporinus octofasciauts (Loct) was found in points 1 and 2 of the same river.

The cascudo Hypostomus strigaticeps was frequently captured in the Corumbataí River Basin, especially at points with shade between $0-25 \%$ (248 individuals). Within the four categories of shade, this species was associated with points of low shade $\left(X^{2}=437.13\right.$; df $=3$; $\mathrm{p}<0.01)$.

The principal components analysis (PCA) based on the habitat elements data indicates a positive association between the first axis with the river order $(35.72 \%$ of explication), the second axis with the vegetative cover and the preservation state of the riparian forest $(27.96 \%$ of explication) and an negative association between the third axis with pasture presence (12.54\% of explication) (Table 1). 

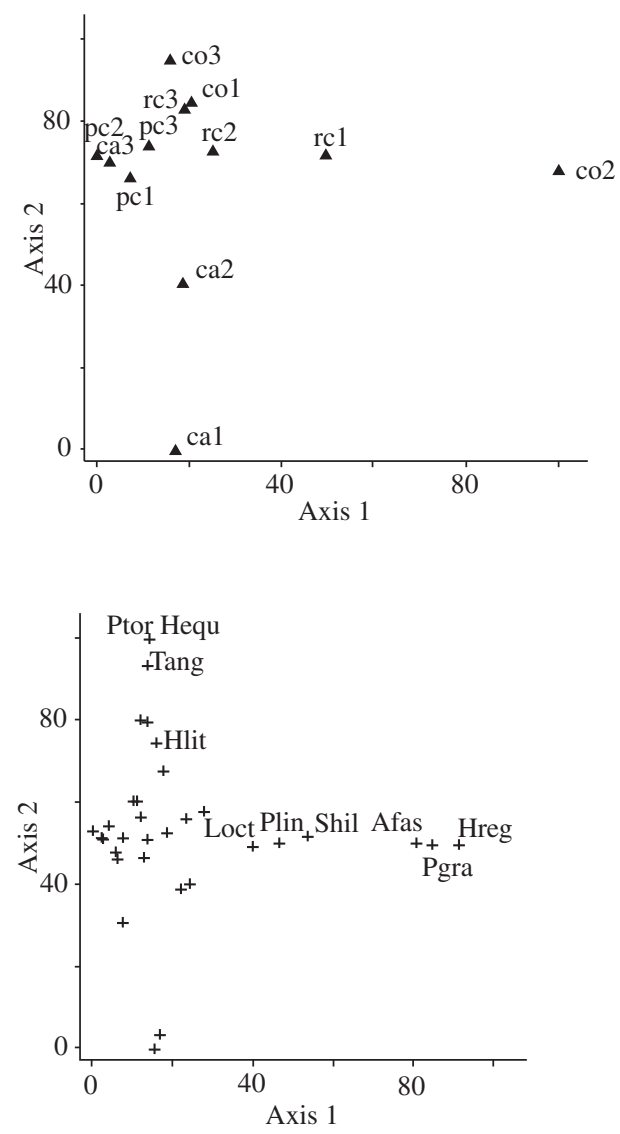

Figure 1. Projection of the 12 sites scores and 35 species obtained with the detrended correspondence analysis (DCA). The eigenvalue of axis $1=0.713$ and axis $2=0.319$. Rivers Corumbataí (co), Passa Cinco (pc), Ribeirão Claro (rc) and Cabeça (ca). Collections from March to June (1) and from September to December (2).

Table 1. Principal components analysis of the surrounding landscape environmental variables of the sites. Values larger than 0.5 are presented in bold.

\begin{tabular}{lrrr}
\hline & \multicolumn{3}{c}{ Eigenvectors } \\
\cline { 2 - 4 } & \multicolumn{1}{c}{$\mathbf{1}$} & $\mathbf{2}$ & $\mathbf{3}$ \\
\hline Eigenvalue & 2.86 & 2.24 & 1.00 \\
explication (\%) & 35.72 & 27.96 & 12.54 \\
accumulated (\%) & 35.72 & 63.68 & 76.23 \\
Variables & & & \\
River order & $\mathbf{0 . 5 2}$ & 0.05 & -0.28 \\
Cover & -0.24 & $\mathbf{0 . 5 4}$ & -0.20 \\
Riparian forest & -0.34 & $\mathbf{0 . 5 1}$ & -0.12 \\
preservation & & & \\
Presence of Eucalyptus & -0.28 & -0.36 & -0.05 \\
Presence of sugar cane & 0.35 & 0.42 & 0.26 \\
Presence of pastures & -0.27 & -0.14 & $\mathbf{- 0 . 7 5}$ \\
Sewage & -0.29 & -0.29 & 0.39 \\
Declivity stability & -0.45 & 0.19 & 0.31 \\
\hline
\end{tabular}

In the analysis of variance (ANOVA), a significant difference was not found between the different rivers (axis 1: $\mathrm{X}^{2}=7.308 ; \mathrm{df}=3 ; \mathrm{p}=0.063$ and axis $\left.2: \mathrm{X}^{2}=5.519 ; \mathrm{df}=3 ; \mathrm{p}=0.137\right)$.

Species richness was significantly predicted by the number of individuals and the scores derived from the second principal component $\left(\mathrm{r}^{2}=0.974 ; \mathrm{F}=184.98\right.$; $\mathrm{p}<0.001$ ) (Table 2 and Figure 2).

\section{Discussion}

The DCA results indicate a low spatial heterogeneity when the primary structure of the fish assemblage (species composition and distribution abundance) is considered (Figure 1). This is supported by the ANOVA, where a significant difference was not found between the rivers using the scores of the axes 1 and 2 of the DCA.

These results coincide with those of Toepfer et al. (1998), because of the small size of the Corumbataí River Basin, which is around $1700 \mathrm{~km}^{2}$. These authors state that there exists a smaller assemblage gradient in ecoregions, or in this case, in the hydrographic basin, than in larger regions, principally because of the high mobility of the fish.

Table 2. Multiple regression analysis of species richness versus number of individuals $(\mathrm{LnN})$ and second principal component (PCA2) which represented the vegetation cover and the preservation state of the riparian forest.

\begin{tabular}{lccrc}
\hline & Coefficient & SE & t & p \\
\hline PCA2 & 1.353 & 0.446 & 3.033 & 0.013 \\
LNN & 2.501 & 0.133 & 18.854 & $<0.01$ \\
\hline
\end{tabular}

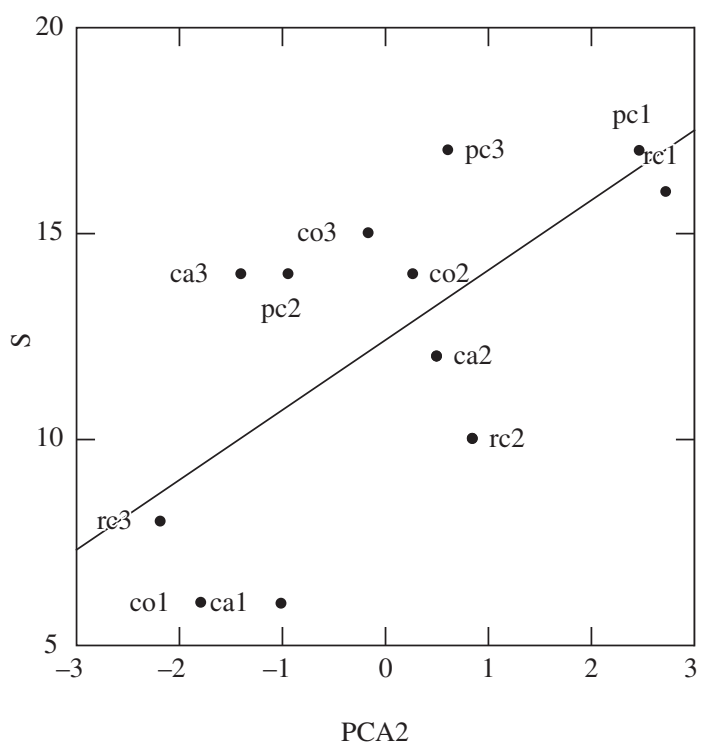

Figure 2. Dispersion diagram and regression line between species richness $(\mathrm{S})$ and the axis of the principal component analysis 2 (PCA2) which represented the vegetative cover and the preservation state of the riparian forest. 
The logarithm of the number of individuals was a good predictor of species richness (Table 2). This can be interpreted as a result of the sample size effect (Connor and McCoy, 2001).

According to classic ecological models like the species-area relationship (MacArthur and Wilson, 1967) and the river continuum concept (Vannote et al., 1980), it is expected that an increase in the number of species will be found as the order of the river increases (Angermeier and Schlosser, 1989; Osborne and Wiley, 1992). In accordance with these models, river sections near to the headwaters show lower species richness than those downstream in the Corumbataí River Basin (Cetra, 2003). This was found at point 1 of both the Cabeça and Corumbataí rivers.

The preceding descriptive models are insufficient to understand the complex landscape of the Corumbataí River Basin. It is necessary to consider the relationships within the river together with its surroundings because the landscape consists of a mosaic made up of small areas connected by corridors that permit contact between the environments.

The results of this work agree with the idea that the riparian forests is associated to fish fauna. Although they are located in the more elevated river sections, point 1 of the Passa Cinco and Ribeirão Claro rivers exhibit the best conditions in terms of riparian forest conservation, and more species were captured at these locations (Figure 2).

This situation can be explained through the environmental characteristics of these points. The first site of the Passa Cinco River is characterized by a typical "cuesta" relief with rocky outcrops and steep but stable run-off trenches. The marginal vegetation is responsible for $51-75 \%$ shading, with partial deforestation, thin trees, bushes and herbs and some areas covered by grasses. The river bed is rocky and graveled with a small amount of sand. A large quantity of habitats occur, amongst them pools, runs and riffles. This point is frequented by sport fishermen seeking lambaris Astyanax spp.

At the first site of the Ribeirão Claro River, 16 species and 39 individuals were captured, which could be considered outliers in the relation of species richness to abundance. This can be explained by the environmental characteristics of this point: a lightly undulated relief with planar areas, a steep and stable river bank, flooded areas and conserved riparian vegetation, with shading above $75 \%$. The presence of tabaranas Salminus hilarii at this point (Figure 1), a predator population, suggests the biological integrity of this location. This indicates the high diversity of other species in this area, due to the high degree of the environmental selectivity of this species and its position in the food chain (Alves and Pompeu, 2001).

The low richness of point 3 of the Ribeirão Claro River may be a function of the intense anthropic actions. It is located $1 \mathrm{~km}$ above the confluence with the Corumbataí River, which theoretically indicates the possibility of high species richness. But, its location upstream from the second dam and downstream from the untreated Rio Claro sewage outlet contributes to a mostly organic river bed. In addition, the marginal vegetation is made up of pasture grasses, vines and Eucalyptus sp., providing 0 to $25 \%$ shading. The aquatic vegetation consists of floating macrophytes and grasses. Eighteen individuals of caborja Hoplosternum littorale were collected at this point from September to December. The occurrence of this species is explained by its ability to cease feeding and use its intestine strictly for aerial breathing (Signorini, 1999).

Like Power (1984), the data of this study suggest an association between a low shade level and the cascudos Hypostomus strigaticeps. Hahn et al. (1997) classify it as a detritivore, having identified various generas of diatoms, filamentous algae, insect larvae (Chironomidae) and Nematoda in its stomach, which confirms that these fish are important controllers of alga populations. This data also indicates that with low levels of shade, these sites become autotrophic (Angermeier and Karr, 1983; Allan, 1995), creating more food for this species.

The interpretation of these results cannot be ignored. It demonstrates that intense anthropic action has caused the elimination of natural heterogeneity, the presence of which would have theoretically supported greater biological and environmental diversity (Magurran, 2004; Begon et al., 1996).

Acknowledgments - The authors are grateful to the anonymous reviewer for suggestions and coments on an earlier version of the manuscript.

\section{References}

ALLAN, JD., 1995. Stream Ecology: structure and function of running water. Chapman \& Hall, New York, 388p.

ALVES, CBM. and POMPEU, PS., 2001. Peixes do Rio das Velhas: passado e presente. Segrac, Belo Horizonte, 198p.

ANGERMEIER, PL. and KARR, JR., 1983. Fish communities along environmental gradients in a system of tropical stream. Environmental Biology of Fishes, vol. 9, p. 117-35.

ANGERMEIER, PL. and SCHLOSSER, IJ., 1989. Species-area relationships for stream fishes. Ecology, vol. 70, p. 1450-1462.

ATLAS ambiental da bacia do rio Corumbataí, 2002, Available in: <http:// www.rc.unesp.br/igce/ ceapla/atlas>. Date of consulting 15/5/2002.

BARRELLA, W., PETRERE, M., SMITH, WS. and MONTAG, LFA., 2000. As relações entre as matas ciliares, os rios e os peixes. In RODRIGUES, R.R. \& LEITÃO FILHO, H.F, (eds.), Matas ciliares: conservação e recuperação. EDUSP, São Paulo.

BEGON, M., HARPER, JL. and TOWNSEND, CL., 1996. Ecology: individuals, populations and communities. Blackwell Science, Oxford, 876p.

CETRA, M., 2003. Caracterização das assembléias de peixes da bacia do rio Corumbataí (SP). (Dissertação de Mestrado) - Universidade de São Paulo, São Carlos, 88p. 
CONNOR, EF. and McCOY, ED., 2001. Species-area relationships. Encyclopedia of Biodiversity. California: Academic Press.

GAUCH, HG., 1982. Multivariate analysis in community ecology. Cambridge University Press, Cambridge, 298p.

HAHN, NS., FUGI, R., ALMEIDA, VLL., RUSSO, MR. and LOUREIRO, VE., 1997. Dieta e atividade alimentar de peixes do reservatório de Segredo. In AGOSTINHO, AA. and GOMES, LC., (eds.), Reservatório de Segredo: bases ecológicas para o manejo, EDUEM, Maringá.

HARRIS, JH., 1995. The use of fish in ecological assessments. Australian Journal of Ecology, vol. 20, no. 1, p. 65-80.

MacARTHUR, RH. and WILSON, EO., 1967. The Theory of Island Biogeography. Princeton University Press, Princeton.

MAGURRAN, AE., 2004. Measuring Biological Diversity. Blackwell Publishing, Oxford, 256p.

MARSH-MATTHEWS, E. and MATTHEWS, WJ., 2000. Geographic, terrestrial and aquatic factors: which most influence the structure of stream fish assemblages in the Midwestern United States? Ecology of Freshwater Fish, vol. 9, p. 9-21.

McGARIGAL, K., CUSHMAN, S. and STAFFORD, S., 2000. Multivariate Statistics for Wildlife and Ecology Research. Springer-Verlag, New York, 283p.

POWER, ME., 1984. Habitat quality and the distribution of algae-grazing cascudos in a Panamanian stream. Journal of Animal Ecology, vol. 53, p. 357-374.
OSBORNE, LL. and WILEY, MJ., 1992. Influence of tributary spatial position on the structure of warmwater fish communities. Canadian Journal of Fisheries and Aquatic Sciences, vol. 49, p. 671-681.

SIGNORINI, CE, 1999. Alimentação de H. litoralle Hancock (Callichthyidae, osteichthyes) do rio Piracicaba e rio Corumbataí, Estado de São Paulo. PhD Thesis Universidade Estadual Paulista, Rio Claro, 156p.

TOEPFER, CS., WILLIAMS, LR., MARTINEZ, AD. and FISHER, WL., 1998. Fish and habitat heterogeneity in four streams in the central Oklahoma/Texas plains ecoregion. Proceedings of the Oklahoma Academy of Science, vol. 78, p. 41-48.

VANNOTE, RL., MINSHALL, GW., CUMMINS, KW., SEDELL, JR. and CUSHING, CE., 1980. The river continuum concept. Canadian Journal of Fisheries and Aquatic Sciences, vol. 37, p. 130-137.

VIANA, VM. and MENDES, JCT., 1997. Recuperação da Cobertura Florestal da Bacia do Rio Corumbataí. In NASSIF, AMA., SILVA, ER., MERLI, GL., MENDES, JC., FREIXEDAS, V. and VIANA, VM. (eds.), Recuperação Florestal e Desenvolvimento Sustentável na Bacia do Rio Corumbataí. Piracicaba: SEMAE.

ZALEWSKI, M., THORPE, JE. and NAIMAN, RJ., 2001. Fish and riparian ecotones - a hypothesis. Ecohydrology \& Hidrobiology, vol. 1, p. 11-24. 
